Poznańskie Studia Teologiczne 27(2013), s. 193-210.

Jan Grzeszczak

Uniwersytet im. Adama Mickiewicza w Poznaniu

Wydział Teologiczny

\title{
Bonifacy VIII wobec średniowiecznych zwyczajów grzebalnych. Bulla Detestande feritatis i jej interpretacje
}

Dnia 27 września 1299 roku papież Bonifacy VIII (1294-1303) promulgował bullę, zaczynającą się od słów Detestande feritatis, w której zakazał dalszego praktykowania średniowiecznego zwyczaju dzielenia ludzkich zwłok na części, gotowane następnie w wodzie w celu oddzielenia kości od tkanek miękkich ${ }^{1}$. Celem tych zabiegów, określonych przez papieża mianem „strasznego zwyczaju" (mos horribilis), było pozyskanie szczątków kostnych osoby zmarłej daleko od ustalonego wcześniej miejsca pochówku. Pozostałości kostne można było następnie łatwo przetransportować, nie narażając się na niedogodności wynikające z rozkładu ciała. Dokument ten stał się w późniejszych wiekach jednym z najbardziej znanych aktów prawnych, wydanych za pontyfikatu Bonifacego VIII, a historia anatomii długo uznawała papieską decyzję za prawdziwy hamulec w rozwoju tej dyscypliny naukowej². W jakich okolicznościach doszło do promulgowania bulli? Co spowodowało, że Bonifacy VIII zaangażował się, również emocjonalnie, w uporządkowanie średniowiecznych zwyczajów grzebalnych? $\mathrm{Na}$ te i inne pytania dotyczące Detestande feritatis spróbujemy odpowiedzieć w niniejszym artykule.

Dzielenie zwłok na części, a następnie gotowanie ich w wodzie celem uzyskania samych kości, które składano następnie w ustalonym wcześniej miejscu pochówku, praktykowane było w północnej Europie, a zwłaszcza w Niemczech, już od czasów karolińskich. Trzynastowieczny gramatyk i nauczyciel retoryki

\footnotetext{
${ }^{1}$ Tekst bulli Detestande feritatis - zob. Aneks.

${ }^{2}$ Zob. A. Paravicini Bagliani, La papauté du XIII ${ }^{e}$ siècle et la renaissance de l'anatomie, w: tenże, Medicina e scienze della natura alla corte dei papi nel Duecento, Biblioteca di Medioevo Latino, 4, Spoleto 1991, s. 267-279; M.N. Alston, The Attitude of the Church towards Dissection before 1500, „Bulletin of the History of Medicine” 16 (1944), s. 221-238; E.A.R. Brown, Death and the Human Body in the Later Middle Ages. The Legislation of Boniface VIII on the Division of the Corpse, „Viator” 12 (1981), s. 221-270; taż, Authority, the Family, and the Death in Late Medieval France, "French Historical Studies" 16 (1990), s. 803-832; K. Park, The Life of the Corpse: Division and Dissection in Late Medieval Europe, "Journal of the History of Medicine and Allied Sciences" 50 (1995), s. 111-132.
} 
Boncompagno da Signa określa je mianem ,zwyczaju niemieckiego" (mos teutonicus) i przeciwstawia sposobowi stosowanemu przez Rzymian, którzy najpierw usuwali wnętrzności, a następnie konserwowali ciało, mocząc je w słonej wodzie $^{3}$. Ciała wielu znanych niemieckich dostojników wczesnego średniowiecza zostały potraktowane w ten sposób. W czasie kampanii prowadzonych przez Fryderyka Barbarossę w północnej Italii zwłoki jego rycerzy oraz duchownych i świeckich członków cesarskiej świty poddawano gotowaniu, a kości wysyłano do Niemiec. Podobny los spotkał ciało samego cesarza po jego śmierci w czasie trzeciej krucjaty ${ }^{4}$. W XIII wieku mos teutonicus upowszechnił się również w Anglii i Francji. Popularne stało się mnożenie miejsc, w których składano różne szczątki tej samej osoby (kości, serce, wnętrzności), jednak kości zmarłego uznawano za najszlachetniejszą część zwłok, dla której rezerwowano najbardziej okazały nagrobek $^{5}$. O skali zjawiska w XIII wieku świadczą losy ciał wielu członków angielskich i francuskich dynastii oraz najwyższych dostojników Kościoła. Najwybitniejszy spośród nich, król Francji Ludwik IX Święty zmarł w Tunisie w czasie krucjaty przeciwko muzułmanom. Na łożu śmierci potwierdził wyrażone wcześniej pragnienie bycia pochowanym w Saint-Denis, obwarowane zastrzeżeniem, że podparyskie opactwo ma być miejscem jego ostatecznego spoczynku tylko w przypadku, gdy umrze w takiej odległości od niego, która umożliwi transport zwłok i pogrzeb oraz gdy śmierć zabierze go z tego świata w kraju niechrześcijańskim ${ }^{6}$. W 1270 roku z ciała króla wydobyto wnętrzności, które otrzymał jego brat Karol I Andegaweński i pochował w sycylijskim Monreale ${ }^{7}$. Kości, oddzielone od ciała poprzez gotowanie w wodzie, opuściły Afrykę wraz z armią krzyżowców.

Los zwłok następcy Ludwika IX Świętego, Filipa III Śmiałego, sprowokował paryskich teologów do dysputy, której przedmiotem była integralność ludzkiego ciała. Król zmarł w Perpignan dnia 5 października 1285 roku, a jego doczesne szczątki poddano takiej samej procedurze, jaką 15 lat wcześniej zastosowano wobec ciała jego ojca. Zmiana ostatniej woli zmarłego w odniesieniu do miejsca pochówku serca, na jaką zdecydował się jego syn Filip IV Piękny, doprowadziła do gorszących kłótni. Na Wielkanoc 1286 roku trzej paryscy teologowie, Henryk z Gandawy, Godfryd z Fontaines i Gerwazy z Mont-Saint-Eloi, odbyli dysputę, w trakcie której, nie potępiając zwyczaju dzielenia zwłok na części, podkreślili jednak, że najlepszym rozwiązaniem jest pochowanie ciała w ca-

${ }^{3}$ Zob. A. Paravicini Bagliani, La papauté, s. 273.

${ }^{4}$ Zob. E.A.R. Brown, Death and the Human Body, s. 227-228.

${ }^{5}$ Philippe Ariès uważa, że uprzywilejowanie kości wynikało najprawdopodobniej z faktu, że stanowią najtrwalszą część ciała, zauważa też widoczny w średniowieczu „ciekawy [...] paralelizm pomiędzy podziałem zwłok na ciało, kości, serce i wnętrzności, a podziałem istoty na ciało i duszę" - zob. P. Ariès, Człowiek i śmierć, thum. E. Bąkowska, Warszawa 1992, s. 257.

${ }^{6}$ Zob. E.A.R. Brown, Death and the Human Body, s. 231.

${ }^{7}$ Zob. tamże. 
łości. Najgorętszym zwolennikiem tej tezy był Godfryd z Fontaines, który stwierdził, że dzielenie ciała jest działaniem wbrew naturze, a pozostawienie go nietkniętym sprawia, że jest gotowe do zmartwychwstania, choć jasne jest, że również podział ciała na części nie stanowi przeszkody dla mocy Boga, sprawiającej, że zmarli powstaną z grobu ${ }^{8}$. Teolog postulował też, by chronić ciało przed innymi szkodami niż te, które wywołuje naturalny proces rozkładu, i kontynuował w ten sposób myśl św. Augustyna, według którego proces gnicia zwłok ludzkich „nie uchybia w niczym prawom danym przez Stwórcę i Urządziciela świata, zawiadującego pokojem wszechstworzenia" ". Paryska debata na temat problemów związanych z integralnością ludzkiego ciała po śmierci trwała kilka lat $i$, jak się wydaje, jej echem były niektóre sformułowania, jakie można znaleźć w bulli Bonifacego VIII. Godfryd z Fontaines określa zwyczaj dzielenia zwłok mianem „okrucieństwa” i „nieludzkiego traktowania” (atrocitas, inhumanitas) ${ }^{10}$. Ukazane wyżej rozwiązania paryskich teologów, którzy opowiadają się za pozostawieniem zwłok naturze, zgodne są z przekonaniem św. Augustyna, wyrażonym w jego Państwie Bożym: ,Jeśli się [...] nie poczyni starań żadnych, by ciało zachować od rozkładu, lecz zostawia się je naturze samej, to jest ono tak długo niejako niepokojone przez przeciwne wyziewy, niezgodne z czuciem naszym (jest to bowiem to przykre wrażenie, które zmysłom naszym sprawia zgnilizna), dopóki nie uzgodni się z pierwiastkami świata"l1. W tym kontekście bulla Detestande feritatis nakazuje pochówek prowizoryczny i poddanie w ten sposób ciała naturalnemu procesowi rozkładu ${ }^{12}$.

Kuria rzymska nie pozostawała na uboczu debaty, jaka w ostatnich dwóch dekadach XIII wieku zajmowała paryskie środowisko uniwersyteckie. O zainteresowaniu tematem świadczą, między innymi, testamenty kardynałów z otoczenia papieży tego okresu ${ }^{13}$. Na podstawie ich analizy można stwierdzić, że mos teutonicus podzielił purpuratów na dwie, różniące się podejściem do niego, grupy. Wyrażając ostatnią wolę, kardynałowie pochodzący z terenu Italii unikali rozwiązań, które mogłyby wystawić ich ciała na ryzyko podzielenia na części. Pochodzący z Genui Ottobono Fieschi, późniejszy Hadrian V (1276), jeszcze jako kardynał wybrał na miejsce wiecznego spoczynku genueńską katedrę i nakazał

\footnotetext{
${ }^{8}$ Zob. tamże, s. 239; A. Paravicini Bagliani, Bonifacio VIII, Torino 2003, s. 218.

${ }_{9}^{9}$ Zob. św. Augustyn, Państwo Boże, XIX, XII, thum. W. Kubicki, Kęty 1998, s. 778.

${ }^{10}$ Huiusmodi separatio quamdam atrocitatem et inhumanitatem importet - cyt. za E.A.R. Brown, Death and the Human Body, s. 239, przyp. 70.

${ }^{11}$ Św. Augustyn, Państwo Boże, XIX, XII, thum. W. Kubicki, s. 778.

${ }^{12} \mathrm{Sed}$, ut defunctorum corpora sic impie ac crudeliter non tractentur, deferantur ad loca, in quibus viventes elegerint sepeliri, aut in civitate, castro vel loco vicino ecclesiastice sepulture tradantur ad tempus, ita quod demum, incineratis corporibus ad alias, ad loca, ubi sepulturam elegerint, deportentur et sepeliantur in eis.

${ }^{13}$ Zob. A. Paravicini Bagliani, I testamenti dei cardinali del Duecento, Miscellanea della Società Romana di Storia Patria, 25, Roma 1980.
} 
jej kanonikom, by jego ciało zostało tam sprowadzone w czasie nieprzekraczajacym dwóch lat od śmierci ${ }^{14}$. Gdyby jednak zgon nastąpił poza Genua, kardynał zastrzegł sobie, by jego ciało zostało czasowo pochowane w najbliższym kościele franciszkanów aż do momentu, gdy kości będą mogły spocząć w umiłowanej katedrze $^{15}$. Zapobiegliwy genueński purpurat zapisał zarówno kanonikom, jak i franciszkanom odpowiednią sumę pieniędzy, aby spełnili jego życzenie. Mamy w tym przypadku do czynienia ze wskazaniem takiej procedury pochówku, która pozwoliłaby na uniknięcie podziału ciała na części. Warto też zauważyć, że Ottobono Fieschi był jednym z pierwszych dostojników, którzy na początku lat sześćdziesiątych XIII wieku umożliwili karierę kurialną początkującemu wówczas kanonikowi Benedyktowi Caetaniemu, późniejszemu kardynałowi i papieżowi ${ }^{16}$. Wybitny średniowieczny dekretalista, kardynał Henryk z Suzy (†1271), nie był szczególnie zainteresowany tym, co stanie się po śmierci z jego ciałem, i w testamencie, noszącym datę 29 października 1271 roku, nakazał, by w przypadku, gdy umrze daleko od Rzymu, został pochowany w katedrze metropolii, na terenie której nastąpi zgon ${ }^{17}$. Gdyby jednak dystans dzielący ją od miejsca śmierci był zbyt duży, by umożliwić transport całych zwłok, Hostiensis kazał pochować wnętrzności, jako najbardziej podatną na rozkład część ciała, w najbliższym kościele parafialnym, a resztę (residuum) w katedrze ${ }^{18}$.

Po roku 1305 kuria podążała za papieżem przez Francję i dla kardynałów z Italii problem transportu zwłok do wybranego przez nich miejsca wiecznego spoczynku nie stracił na aktualności. Wielu z nich pragnęło choć po śmierci wyrwać się z raczej mało dla nich gościnnej ziemi i znaleźć się w ukochanym Rzymie $^{19}$. Należy jednak zaznaczyć, że testamenty kardynałów pochodzących z Italii i towarzyszących papieżom we Francji i Awinionie, takich jak Giovanni Boccamazza, Riccardo Petroni, Guglielmo Longhi, Iacopo Caetani Stefaneschi, Luca Fieschi czy Napoleone Orsini, choć zawierają wskazanie, by miejscem po-

${ }^{14}$ Subsequenter, sperans de intercessionibus beati Iohanni Baptiste, sepulturam eligo in cathedrali ecclesia Ianuensi, ubi ipsius Precursoris diu cineris conservantur. Et volo quod ubicumque me mori contigerit, canonici Ianuenses corpus meum ad ipsam ecclesiam faciant deportari infra duos annos, et pro expensis deportationis lego eis libr. quinquaginta ianuen. - A. Paravicini Bagliani, I testamenti, s. 143.

${ }^{15}$ Zob. tamże, s. 143-144.

${ }^{16}$ Zob. A. Paravicini Bagliani, Bonifacio VIII, s. 15-18, 216.

${ }^{17}$ [...] si contingat me decedere in Romana Curia vel prope, eligo sepulturam in ecclesia ordinis Predicatorum propinquiori loco in quo decedam. Si vero citra Curiam et longe ab ea, - puta ultra montes -, tunc eligo sepulturam meam in ecclesia metropolitana provincie in qua decedam. Quod si propter nimiam distantiam totum corpus ad metropolitanam ecclesiam portari non posset, exenteretur corpus, et intestinis apud ecclesiam in cuius parochia me decedere contingerit dimissis, residuum ad metropolitanam ecclesiam deportetur - A. Paravicini Bagliani, I testamenti, s. 134.

${ }^{18}$ Zob. tamże.

${ }^{19}$ Zob. E. Duprè Theseider, Roma dal comune del popolo alla signoria pontificia (1252-1377), Bologna 1952, s. 385. 
chówku był Rzym lub inne miasta Italii, to jednak brak w nich jakiejkolwiek wzmianki o dzieleniu zwłok ${ }^{20}$. Można to wytłumaczyć wyrażeniem przez nich ostatniej woli już po promulgacji bulli Detestande feritatis, choć należy stwierdzić, że generalnie dla kardynałów z Italii, sporządzających swoje testamenty na przełomie XIII i XIV wieku, mos teutonicus stanowiło rozwiązanie, z którego nie chcieli korzystaćén

Inaczej postępowali kardynałowie pochodzący z Francji. Testament Hugona Aycelina, kardynała-biskupa Ostii, zawiera cały szereg interesujących szczegółów, dotyczących miejsca pochówku i sposobu transportu zwłok. W przypadku tego zmarłego w 1297 roku w Rzymie wysokiego dostojnika kościelnego, pochodzącego z okolic Clermont-Ferrand, mamy do czynienia z dwoma testamentami: jeden z nich reguluje sprawy kardynała na północ od Alp, a drugi dotyczące Italii ${ }^{22}$. Hugo Aycelin wyraźnie zaznaczył, że niezależnie od tego, gdzie przyjdzie mu umrzeć, chce być pochowany w Clermont-Ferrand, w tamtejszym klasztorze dominikanów ${ }^{23}$. Szczegółowe wskazówki, zawarte w jego ostatniej woli, dotyczą sposobu postępowania w zależności od miejsca zgonu. Kardynałowi zależało na tym, by jego ciało dotarło w całości do Clermont-Ferrand i dlatego, jeśli przyjdzie mu umrzeć w miejscu umożliwiającym transport całych zwłok, zalecał, by zostały zabalsamowane, zaszyte w skórzanym worku lub przewiezione w inny, bliżej nieokreślony sposób ${ }^{24}$. Jeśli zgon nastapi daleko od wskazanego w testamencie miejsca wiecznego spoczynku, testator zalecał podwójny pochówek: ciało i wnętrzności (caro et viscera) miały spocząć w najbliższym klasztorze dominikanów, natomiast kości zostać przetransportowane do Clermont-Ferrand ${ }^{25}$. Częstą w średniowieczu praktykę balsamowania i zaszywania ciała w skórzanym worku stosowano podczas transportu całych zwłok, natomiast podwójny pochówek zakładał oddzielenie kości od ciała poprzez gotowanie go w wodzie.

Kardynał Hugo Aycelin sporządził obydwa testamenty w Orvieto w dniu 24 sierpnia 1297 roku, czyli na dwa lata przed ogłoszeniem przez Bonifacego VIII bulli Detestande feritatis. Ówczesny komentator papieskich tekstów prawniczych, kardynał Jean Lemoine, twierdzi, że bezpośrednim powodem reakcji Bonifacego VIII na rozpowszechniony zwyczaj grzebalny była śmierć kardynała Nicolasa de Nonancourt, zmarłego dnia 23 września 1299 roku, a więc zaledwie

${ }^{20}$ Zob. A. Paravicini Bagliani, I testamenti, s. 354, 407, 414, 416, 418, 449, 451, 460, 466.

${ }^{21}$ Zob. tenże, La vita quotidiana alla corte dei papi del Duecento, Roma - Bari 1996, s. 245-247.

${ }^{22}$ Zob. tamże, s. 276-320.

${ }^{23}$ Zob. tamże, s. 292, 299.

${ }^{24}$ Volumus autem quod corpus nostrum integrum portetur Claromontem, vel paratum cum balsamo vel in coriis vel aliter, si sit quoquo modo possibile - tamże, s. 300.

${ }^{25}$ Zob. tamże, s. 292, 299. 
cztery dni przed promulgowaniem Detestande feritati ${ }^{26}$. Niestety, nie zachował się testament tego francuskiego purpurata, można jednak przypuszczać z dużą dozą prawdopodobieństwa, że zawierał polecenie, by poddać zwłoki takiej samej procedurze, jaką dwa lata wcześniej Hugo Aycelin zalecał w odniesieniu do swojego ciała. Bardzo krótki czas, jaki upłynął pomiędzy śmiercią dostojnika i promulgacją bulli, sugeruje, że tak szybka reakcja papieża mogła być podyktowana uczuciem gniewu i obrzydzenia, których ślady dają się zauważyć w wydanym przez niego dokumencie ${ }^{27}$.

Czytelnik może w tym miejscu zadać pytanie o przyczynę różnic w postępowaniu średniowiecznych purpuratów z Europy Środkowej i pochodzących z Italii. Jest to $\mathrm{w}$ gruncie rzeczy pytanie o mos teutonicus. Problem nie jest tak odległy czasowo, jak mogłoby się na pierwszy rzut oka wydawać. W 2008 roku prasa włoska zajęła się dyskutowaną w pewnych kręgach ewentualnością pochowania w Polsce serca papieża Jana Pawła II. Zwyczaj ten, znany i stosowany czasami w przeszłości w naszym kraju w przypadku pochówków wielkich Polaków, został uznany nad Tybrem za „nowość w długiej historii pochówków papieży”28. W sformułowaniu tym pobrzmiewa echo ukazanych wyżej średniowiecznych zwyczajów pogrzebowych z terenu Italii, zwłaszcza że tym, który zabrał głos w tej sprawie we włoskiej prasie, był znakomity mediewista Agostino Paravicini Bagliani $^{29}$. Ten ostatni uważa ponadto, że przywołana wyżej gwałtowna reakcja Bonifacego VIII na decyzję jego kardynała może być potraktowana jako specyficznie ,południowoeuropejski” przyczynek do problematyki integralności ludzkiego ciała ${ }^{30}$.

Katharine Park odnosi się sceptycznie do konkluzji włoskiego mediewisty, podając jako przykład Półwysep Iberyjski, gdzie już w XIII wieku praktykowa-

${ }^{26}$ Huic statuto causam dedit bonae memoriae N. tituli sancti Laurentii in Damaso presbyter cardinalis - cyt. za A. Paravicini Bagliani, I testamenti, s. 65, przyp. 1; zob. tenże, Bonifacio VIII, s. 215; E.A.R. Brown, Death and the Human Body, s. 248-249.

${ }^{27}$ Zob. A. Paravicini Bagliani, Bonifacio VIII, s. 215.

${ }^{28}$ Zob. tenże, Sarebbe la prima volta nella storia dei Papi, w: http://ricerca.repubblica.it/repubblica/archivio/repubblica/2008/04/08. [dostęp 29.06.2009]; „Nie ma praktyki dzielenia ciat papieży”, w: http://wiadomości.gazeta.pl/Wiadomości/2029020,80708,5183470.html [dostęp 29.06.2009].

${ }_{29}$ Włoski mediewista zauważa jednak, że od XVI wieku pojawia się w przypadku pochówków papieży nowy zwyczaj, związany z balsamowaniem ich ciał. Kiedy w 1513 roku zmarł Juliusz II, jego wnętrzności zostały pochowane osobno w podziemiach bazyliki watykańskiej, co stanowiło nowość w dotychczasowej praktyce. Kilkadziesiąt lat później Sykstus V zmarł na Kwirynale i jego wnętrzności złożono w położonym nieopodal kościele świętych Wincentego i Anastazego, gdzie aż do pierwszej połowy XIX wieku składano te części ciała papieży w zachowanych do dzisiaj zapieczętowanych urnach, przechowywanych pod głównym ołtarzem świątyni - zob. A. Paravicini Bagliani, Sarebbe la prima volta, dz. cyt.

${ }^{30}$ Zob. tenże, Storia della scienza e storia della mentalità: Ruggero Bacone, Bonifacio VIII e la teoria della "prolongatio vitae", w: Aspetti della letteratura latina nel secolo XIII. Atti del primo convegno internazionale di studi dell'associazione per il medioevo e l'umanesimo latini (AMUL), Perugia 3-5 ottobre 1983, red. C. Leonardi, G. Orlandi, Perugia - Firenze 1986, s. 249-250. 
no dzielenie ciał zmarłych, a w samej Italii również dokonywano w tym samym czasie sekcji zwłok, aby poznać przyczynę zgonu, a także zdobyć wiedzę medyczną ${ }^{31}$. Charakterystyczne dla Italii jest jednak to, że generalnie unika się w tamtym czasie dzielenia zwłok na części, a ewentualne otwieranie ciał ma najczęściej miejsce w kontekście procedury balsamowania ${ }^{32}$. Chcąc wyjaśnić przyczynę różnic $\mathrm{w}$ podejściu do ludzkiego ciała pomiędzy środkową i południową Europą, należy - zdaniem Katharine Park - pójść nieco dalej i przyjrzeć się ówczesnej antropologii ${ }^{33}$. U schyłku średniowiecza dla mieszkańców Italii śmierć oznacza szybkie i radykalne rozdzielenie duszy i ciała, natomiast na północ od Alp o tym samym procesie mówiono, że ma charakter stopniowej separacji, rozłożonej w czasie ${ }^{34}$. W późnośredniowiecznej Italii ,ja” identyfikuje się przede wszystkim $\mathrm{z}$ duszą $\mathrm{w}$ znaczeniu teologicznym, czyli duchowym, a więc nieśmiertelnym bytem, czasowo ożywiającym materialne ciało i opuszczającym je w momencie śmierci. Dla mieszkańców północnej Europy ,ja” w pewnym stopniu pozostaje w ciele aż do momentu jego ostatecznego rozkładu ${ }^{35}$. Balsamowanie zwłok wyraża w tym kontekście pragnienie przedłużenia obecności życia w rozkładającym się ciele. To ostatnie traktowane jest wręcz jako żywe jestestwo, co w przeciwieństwie do zwyczajów i przekonań właściwych mieszkańcom południowej Europy - przekłada się na podkreślenie roli miejsca pochówku ${ }^{36}$.

Bulla Detestande feritatis świadczy o tym, że Bonifacemu VIII były dobrze znane praktyki, do których odniósł się w tym dokumencie. Można w niej wyróż-

${ }^{31}$ Zob. K. Park, The Life of the Corpse, s. 113-114.

${ }^{32}$ Zob. tamże, s. 114-115.

${ }^{33}$ Zob. tamże.

34 "Focussing on the fourteenth and fifteenth centuries, I will argue that, while Italians envisaged physical death as a quick and radical separation of body and soul, northern Europeans saw it as an extended and gradual process, corresponding to the slow decomposition of the corpse and its reduction to the skeleton and hard tissues, which was thought to last about a year. Thus, while Italians tended to see the recently dead body as inert or inactive, northerners treated it during this liminal period as active, sensitive, or semianimate, possessed of a gradually fading life" - tamże.

${ }^{35}$ Zob. tamże, s. 119.

36 "In the northern context, the continuing identification of the person with the decomposing body would explain the relative prominence of embalming in northern funerary ritual, as an attempt to prolong a continuing and fading life. Furthermore, because the northern corpse was a magical and semianimate subject, still strongly identified with the self, its place of burial was of prime importance; in an age of primitive embalming techniques, to accede to the wishes of the deceased in this regard might well require division of the corpse. On the other hand, to open or dismember the body for doctor to inspect - an act of no conceivabler utility to the deceased, now beyond all medical aid - was an act of objectification and a violation of personal honor. The logic in Italy, I would argue, was reversed. Because the corpse was only a corpse, the castoff of a self now definitively elsewhere, it made no sense to engage in laborious and unsavory efforts to preserve it for distant burial. The person was no longer in the body, so that the signifiance of the particular place of burial was less magical - provided it took place in consecrated soil - than commemorative and metaphorical: a symbol of religious allegiance, family solidarity, or social rang" - tamże, s. 126-127. 
nić cztery części. Jako prawodawca papież już na wstępie zakazał dalszego praktykowania zwyczaju dzielenia ciała na części i gotowania go w wodzie celem wydobycia kości. Podyktowane jest to troską o żywych, a konkretnie o ich spokój ducha, oraz martwych, których ciała nie będą odtąd poddawane nieludzkim procedurom. Po ogłoszeniu decyzji zakazującej dalszego praktykowania potępionego zwyczaju papież dokonał opisu sytuacji, do której odniósł się w bulli. Zauważył też, że tymi, którzy uciekają się do tego typu praktyk, są osoby szlachetnie urodzone bądź obdarzone honorowymi tytułami (nobilis vel dignitatis titulo insignitus). Opis kończy się ponownym wyrażeniem głębokiej dezaprobaty dla tego typu nagannych w oczach Boga i ludzi i obrzydliwych praktyk ${ }^{37}$. W trzeciej części dokumentu Bonifacy VIII występuje jako najwyższy pasterz Kościoła, pełniący powierzoną mu misję wobec wiernych. Ustanawia i nakazuje (Apostolica auctoritate statuimus et ordinamus), by zaprzestano dotychczasowego zwyczaju i zamiast niego wprowadzono pochówek zmarłych na czas konieczny do tego, by ciało uległo całkowitemu rozkładowi, który umożliwiłby przeniesienie pozostałych szczątków na miejsce ostatecznego spoczynku. Bullę kończy przypomnienie sankcji karnych, jakie grożą wykonawcom testamentu, krewnym zmarłego lub innym osobom, nawet piastującym godność biskupią, w przypadku niestosowania się do jej postanowień. Popadają one w ekskomunikę zarezerwowaną Stolicy Apostolskiej, a ciało zmarłego pozbawione ma być chrześcijańskiego pogrzebu.

Kilka miesięcy po ogłoszeniu Detestande feritatis, dnia 18 lutego 1300 roku papież ponownie promulgował bullę bez wprowadzania do niej jakichkolwiek zmian. Znawcy problematyki zauważają w tym przypadku wymowną zbieżność czasową: w tym samym dniu Bonifacy VIII promulgował inną bullę, zaczynającą się od słów Super cathedram, w której ograniczył przywileje zakonów żebraczych w zakresie przepowiadania, spowiedzi i pochówku zmarłych ${ }^{38}$. Pod koniec XIII wieku panowało przekonanie, że franciszkanie i dominikanie zachęcali, zwłaszcza bogatsze osoby, do pochówku w kilku miejscach, mając na uwadze zwiększenie w ten sposób swoich dochodów. W ówczesnych kronikach znaleźć można ostre sformułowania pod adresem braci, pragnących pochować u siebie część ciała bogatej osoby, których porównuje się do psów, czających się w pobliżu trupa i gotowych do wyrwania z niego jakiegoś ochłapu ${ }^{39}$.

Data powtórnego ogłoszenia bulli Detestande feritatis zbiegła się z intensywnymi przygotowaniami do uroczystego ogłoszenia pierwszego Jubileuszu, które

\footnotetext{
${ }^{37}$ Quod non solum divine majestatis conspectui abominabile plurimum redditur, sed etiam humane considerationis obtutibus occurrit vehementius aborrendum.

${ }^{38}$ Zob. E.A.R. Brown, Death and the Human Body, s. 249; A. Paravicini Bagliani, Bonifacio VIII, s. 220.

${ }^{39}$ Aliquid de corporibus quorumcunque potentium morientium sibimet vendicabant, more canum cadaveribus assistentium, ubi quisque suam particulam avide consumendam expectat - cyt. za E.A.R. Brown, Death and the Human Body, s. 249.
} 
miało miejsce w święto katedry św. Piotra Apostoła dnia 22 lutego 1300 roku. Po odbyciu szeregu narad z kardynałami papież dokonał jego uroczystej inauguracji w obecności wiernych, zgromadzonych w bazylice św. Piotra. Nie jest wykluczone, że przypomnienie postanowień bulli, zakazującej dzielenia zwłok i ich gotowania, było częścią działań organizacyjnych, mających na uwadze pielgrzymów, przybywających z całej Europy do Rzymu ${ }^{40}$. Jak łatwo zauważyć, problem chrześcijan zmarłych $z$ dala od miejsca pochodzenia i zamieszkania nabierał w czasie trwania Jubileuszu nowej aktualności.

Co spowodowało, że Bonifacy VIII odniósł się w tak jednoznacznie negatywny sposób do średniowiecznego zwyczaju grzebalnego, popularnego również wśród dostojników z jego bliskiego otoczenia? W 2003 roku minęło 700 lat od śmierci tego papieża średniowiecza, którego historia zapamiętała jako człowieka o silnym charakterze i orędownika odchodzacej w XIV wieku w przeszłość idei średniowiecznej teokracji. Opublikowane z tej okazji interesujące wyniki badań historyków rzucają nowe światło na postać Bonifacego VIII, podobnie jak wydane w 1995 roku akta trwajacego w latach 1303-1311 procesu przeciwko zmarłemu papieżowi, którego promotorem był jego nieprzejednany wróg król Filip IV Piękny i francuski dwór ${ }^{41}$.

Nie jest obecnie możliwe jednoznaczne ustalenie przyczyn uczucia wstrętu, jakiego papież doznawał na myśl o krojeniu i gotowaniu ludzkich zwłok. Nie można wykluczyć, że stało za nim jakieś nieznane nam osobiste traumatyczne przeżycie lub strach przed śmiercią i rozkładem własnego ciała. Wiadomo, że Bonifacy VIII cierpiał na szereg dolegliwości, wiele problemów przysparzała mu zwłaszcza kamica nerkowa ${ }^{42}$. Dolegliwości z nią związane łagodził wodą z Fiuggi, którą regularnie dostarczano mu do Rzymu i Anagni. Wiadomo również, że miał co najmniej sześciu lub siedmiu osobistych lekarzy, korzystał też z rad wybitnych przedstawicieli ówczesnej medycyny ${ }^{43}$. Źródła podają, że papież żywo interesował się postępami tej dziedziny wiedzy, a świadczą o tym między innymi raporty, jakie aragoński poseł w kurii papieskiej Gerau de Albalato słał swojemu królowi. W liście z 14 września 1301 roku poinformował go o tym, że na dworze papieskim panuje przekonanie, że Bonifacy VIII jest naprawdę zainteresowany tylko tym, by znaleźć sposób na długie życie, zgromadzić jak najwięcej pie-

${ }^{40}$ Zob. A. Paravicini Bagliani, Bonifacio VIII, s. 220.

${ }^{41}$ Zob. zwłaszcza: Bonifacio VIII. Ideologia e azione politica. Atti del Convegno organizzato nell'ambito delle Celebrazioni per il VII Centenario della morte. Città del Vaticano-Roma, 26-28 aprile 2004, Bonifaciana, 2, Roma 2006; Le culture di Bonifacio VIII. Atti del Convegno organizzato nell'ambito delle Celebrazioni per il VII Centenario della morte. Bologna, 13-15 dicembre 2004, Bonifaciana, 3, Roma 2006; Boniface VIII en procès. Articles d'accusation et dépositions des témoins (1303-1311). Édition critique, introduction et notes par Jean Coste, Roma 1995.

${ }^{42}$ Zob. A. Paravicini Bagliani, Bonifacio VIII, s. 257-275.

${ }^{43}$ Zob. tamże, s. 261. 
niędzy oraz uczynić swoją rodzinę bogatą i potężną ${ }^{44}$. Ten surowy osąd pojawia się także w aktach procesu papieża. W 1306 roku kardynał Piotr Colonna zeznał, że Bonifacy VIII bardzo często wyśmiewał się z pobożnych rzymskich matron, które miały zwyczaj zwracania się do niego słowami: „Niech Bóg obdarzy cię wiecznością", i mawiał, że najbardziej ucieszyłyby go życzenia długiego i dobrego życia tu na ziemi ${ }^{45}$. Franciszkański dysydent Jakub z Todi twierdzi wręcz, że $\mathrm{w}$ związku z pragnieniem przedłużenia swojego życia papież nie cofnął się przed wykorzystywaniem magii ${ }^{46}$.

Jak twierdzi Agostino Paravicini Bagliani, około roku 1300 w Rzymie zauważyć można znaczący wzrost zainteresowania alchemią, która poprzez zastosowanie złota byłaby w stanie przedłużać ludzkie życie ${ }^{47}$. Próby te, związane z żywym w XIII wieku nurtem retardatio senectutis, zmierzały do wyprodukowania eliksiru na bazie złota, którego przyjmowanie miało dać ciału trwałe zdrowie, długowieczność i równowage psychofizyczną ${ }^{48}$. W Liber sex scientiarum Roger Bacon zachęcał do leczenia się eliksirem na bazie złota, który - jak twierdził franciszkanin - wprowadza ciało w stan doskonałej równowagi (equalis complexio), sprawiającej, że nie ulegnie ono rozkładowi ${ }^{49}$. Teoria ta pojawiła się w kontekście oryginalnych poglądów franciszkańskiego autora, który był przekonany, że będące następstwem upadku pierwszych rodziców skrócenie długości ludzkiego życia można wytłumaczyć nie tylko grzechem, lecz także przyczynami naturalnymi. Rychłe nadejście śmierci (festinatio mortis) jest spowodowane jego zdaniem - nie tylko grzechem, lecz także błędami popełnianymi już przez patriarchów w Starym Przymierzu w tym, co Bacon nazywa regimen sanitatis. Alchemia, perspektywa i astronomia pozwalają je naprawić i przywrócić stan pierwotnej równowagi. Dobroczynne światło ciał niebieskich może, dzięki wysiłkom astronomów, przeniknąc pokarmy i napoje, umożliwiając w ten sposób wydłużenie życia i poprawę jego jakości. Zastosowanie złota sprawia, że ciało

${ }^{44}$ Papa enim non curat nisi de tribus et circa hoc totalis sua versatur intentio, ut diu vivat et ut adquirat pecuniam, tercium ut suos ditet, magnificet et exaltet. De aliqua autem spiritualitate non curat - H. Finke, Aus den Tagen Bonifaz VIII. Funde und Forschungen, Münster i. W. 1902 (reprint: Roma 1964), s. XXXI.

${ }^{45}$ Frequentissime etiam dicebat: „Dicunt iste asine de Urbe, loquens de devotis dominabus Urbis: «Dio ti dia vita eterna», id est: «Deus tibi det vitam eternam». Longe plus placet mihi audire: "Deus det tibi longam vitam»; sed adhuc plus placet audire: «Deus det tibi longam et bonam vitam»” - Boniface VIII en procès, s. 267; zob. A. Paravicini Bagliani, Bonifacio VIII, s. 273-274.

${ }^{46}$ Zob. Jacopone da Todi, Laude, red. G. Mussini, Casale Monferrato 1999, s. 127.

${ }^{47}$ Zob. A. Paravicini Bagliani, Bonifacio VIII, s. 271; tenże, Il corpo del Papa, Torino 1994, s. $300-316$.

${ }^{48}$ Wiadomo, że papież Klemens V (1305-1314) leczył się złotym proszkiem, o czym świadczą floreny, z których ścierano metal, znalezione w papieskim skarbcu po jego śmierci - zob. A. Paravivini Bagliani, Bonifacio VIII, s. 272.

${ }^{49}$ Zob. tamże, s. 219; tenże, Ruggero Bacone, Bonifacio VIII e la teoria della "prolongatio vitae”, w: tenże, Medicina e scienze della natura, s. 343. 
osiaga stan, w którym nie jest już możliwy jego rozkład. Innymi słowy, „stan doskonałej harmonii ciała i nieśmiertelność, która będzie udziałem ludzi w wieczności, po zmartwychwstaniu umarłych, można osiagnąć już tutaj na ziemi, choć

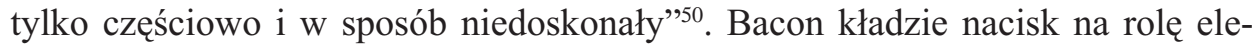
mentów naturalnych $\mathrm{w}$ procesie o charakterze nadprzyrodzonym, podkreślając w ten sposób znaczenie ciała w osiagnięciu stanu równowagi i doskonałości. Logiczną konsekwencją tego typu podejścia będzie również opowiedzenie się za jego nienaruszalnością po śmierci ${ }^{51}$.

Nie wiadomo, czy Bonifacy VIII czytał teksty Rogera Bacona, jest jednak pewne, że poglądy tego ostatniego inspirowały środowiska uniwersyteckie i przenikały na dwór papieski. Cytowany już kardynał Lemoine twierdził, że dzielenie ciała ludzkiego było niedozwolone także przed ogłoszeniem bulli Detestande feritatis, ponieważ jego kształt odzwierciedla niebiańskie piękno i dlatego zabronione jest wszystko to, co mogłoby je splamić czy zdeformowaćs ${ }^{2}$. O tym, że Bonifacy VIII, jeszcze jako kardynał, mógł się wypowiadać publicznie na temat ludzkiego ciała i jego losu po śmierci, świadczy zeznanie, jakie złożył w trakcie wymierzonego przeciwko papieżowi procesu świadek Jakub z Palombary ${ }^{53}$. W kwietniu 1310 roku zeznał, że około 20 lat wcześniej, jako opat benedyktyńskiego klasztoru w Farfie, spotkał się z kardynałem Caetanim w miejscowości Santa Balbina niedaleko Rieti, gdzie usłyszał rozmowę, jaką purpurat prowadził z ludźmi ze swojego otoczenia. Gdy niektórzy z nich wyznali mu, że po śmierci chcieliby znaleźć się w raju, kardynał stwierdził, że jedynym rajem jest ten świat oraz że człowiek nie zmartwychwstanie ${ }^{54}$. Dodał też rzekomo, że głupi są ci, którzy mówią, że kości połączą się z ciałem, bo wystarczy pójść na cmentarz, by przekonać się, że jest to niemożliwe ${ }^{55}$. Jakub z Palombary powtórzył swoje zeznanie latem tego samego roku wobec czterech kardynałów i dominikańskiego inkwizytora Bernarda Gui, którego postać stała się szeroko znana dzięki popularnej powieści Umberto Eco, Imię róż $y^{56}$. Jak twierdzi Jean Coste, troska papie-

${ }^{50}$ Zob. tenże, Ruggero Bacone, s. 344; tenże, Il corpo del Papa, s. 306-309.

${ }^{51}$ Zob. tenże, Ruggero Bacone, s. 345.

${ }^{52}$ Kardynał Lemoine napisał w komentarzu do bulli Detestande feritatis: [...] iste modum esse illicitum ante istam constitutionem: quia corpus humanum, cuius facies ad similitudinem caelestis pulchritudinis est figurata, nec maculari nec defigurari debet - cyt. za E.A.R. Brown, Death and the Human Body, s. 246, przyp. 100.

${ }^{53}$ Zob. Boniface VIII en procès, s. 517-518.

${ }^{54}$ Dicentes aliqui ex dictis familiaribus suis quod vellent esse in paradiso, ipse dominus Benedictus cardinalis dicebat: "Stulti, stulti, quem paradisum vultis? creditis quod sit alius paradisus nisi vita ista et creditis quod resurgat homo postquam moritur? non bene creditis, quia nullus alius paradisus est nisi mundus iste et numquam resurgat aliquis, quia, cum homo mooritur, ita moritur anima sicut corpus" - tamże.

${ }^{55}$ Zob. tamże.

${ }^{56}$ Fatui, fatui, non est paradisus nisi in hoc mundo: creditis vos quod ossa mortuorum que sunt dispersa, possint congregari? Hoc est impossibile - tamże, s. 518. Bernard Gui był w tym 
ża o zachowanie integralności ludzkiego ciała po śmierci, wyrażona w Detestande feritatis, może nadać tym świadectwom ,pewnego posmaku autentyczności” ${ }^{57}$.

Ciekawą wskazówką, pozwalającą poznać lepiej forma mentis Bonifacego VIII, jest ikonograficzny program, widoczny w jego grobowcu, wzniesionym w bazylice watykańskiej już za życia papieża. Mauzoleum Bonifacego VIII, którego wygląd możemy odtworzyć nie tylko na podstawie ocalałych fragmentów, ale również dzięki zapobiegliwości budowniczych z przełomu XVI i XVII wieku, wznoszących aktualną bazylikę św. Piotra i burzących jednocześnie poprzednią konstantyńską światynię, miało kształt kaplicy, zlokalizowanej w nawie głównej, obok jednego z wejść do świątyni ${ }^{58}$. Składał się na nią ołtarz, nad którym umieszczony został sarkofag papieża, stojący obecnie w Grotach Watykańskich, oraz mozaika, najprawdopodobniej autorstwa Jacopa Torritiego, przedstawiająca Madonnę z Dzieciątkiem w otoczeniu świętych Piotra i Pawła, a także Bonifacego VIII, którego św. Piotr poleca Maryi i Jezusowi w charakterystycznym dla średniowiecznej ikonografii geście. Nawiązujący do 20. rozdziału Apokalipsy tron, zwieńczony krzyżem i otoczony drzewami palmowymi, umieszczony został poniżej postaci Madonny ${ }^{59}$. Całość, zwieńczona marmurowym baldachimem i kopuła, wspartymi na czterech kolumnach, ujrzała światło dzienne w maju 1296 roku, co oznacza, że papież wydał polecenie wykonania mauzoleum już w pierwszych miesiącach po wstapieniu na Tron Piotrowy ${ }^{60}$. Był to niewatpliwie trudny okres dla Bonifacego VIII, wybranego na papieża za życia poprzednika, i stąd

czasie inkwizytorem w Tuluzie i brał czynny udział w posiedzeniach komisji, która zbierała się w Groseau u stóp góry Ventoux. Akta procesu nie mówią jednak nic o stosunku dominikanina do Bonifacego VIII. Informacje na temat papieża, zawarte w jego Flores Chronicorum i przeniesione następnie do Liber Pontificalis, pozwalają stwierdzić, że Bernard Gui odnosił się krytycznie do chciwości papieża i jego autorytarnych rządów, nigdzie jednak nie wspominał o jego herezji - zob. tamże, s. 623.

${ }^{57}$ „On peut regretter que dans son excellente étude sur cette pièce [bulla Detestande feritatis - J. G.] Paravicini Bagliani n'ait pris en considération le témoignage cité ici, auquel les préoccupations du pape juriste relativement à l'integrité du corps humain viennent donner une certaine touche d'authenticité" - tamże, s. 518.

${ }^{58} \mathrm{Na}$ temat grobowca Bonifacego VIII - zob. A. Paravicini Bagliani, Bonifacio VIII, s. 109-115; tenże, Il corpo del Papa, s. 219-333; tenże, Le Chiavi e la Tiara. Immagini e simboli del papato medievale, La corte dei papi, 3, Roma 1998; M. Maccarone, Il sepolcro di Bonifacio VIII nella Basilica Vaticana, w: Roma anno 1300. Atti del Congresso Internazionale di storia dell'arte mediavale, Roma 19-24 maggio 1980, Roma 1983, s. 753-771; A.M. Romanini, Ipotesi ricostruttive pe i monumenti sepolcrali di Arnolfo di Cambio, w: Skulptur und Grabmal des Spätmittelalters in Rom und Italien. Akten des Kongresses "Scultura e monumento sepolcrale del tardo medioevo a Roma e in Italia", Roma, 4-6 luglio 1985, hrsg. von J. Garms, A.M. Romanini, Wien 1990, s. 107-128; S. Romano, Visione e visibilità nella Roma papale: Niccolò III e Bonifacio VIII, w: Bonifacio VIII. Ideologia e azione politica, s. 59-76; S. Maddalo, Oblio della memoria. Il destino delle immagini di Bonifacio, w: Bonifacio VIII. Ideologia e azione politica, s. 117-137.

${ }^{59}$ Zob. Ap 20,11.

${ }^{60}$ Zob. A. Paravicini Bagliani, Il corpo del Papa, s. 322-323. 
w delikatnym dla niego momencie mauzoleum miało stanowić dla wiernych, przybywających do bazyliki watykańskiej, kolejne potwierdzenie, że następca Celestyna V, który zrzekł się urzędu, jest jedynym prawowitym następcą apostołów $^{61}$. Czas i okoliczności powstania grobowca oraz zawarte w nim ideowe przesłanie sugerują, że sam Bonifacy VIII był jego pomysłodawca, a mauzoleum miało wyrażać jego wizję papiestwa ${ }^{62}$.

Około roku 1600 rzymski kanonik Giacomo Grimaldi, jeden z ostatnich świadków, którzy oglądali mauzoleum w całości, zanim zostało rozebrane, jak wiele innych grobowców znajdujących się w bazylice watykańskiej, zauważył, że leżąca postać Bonifacego VIII dłuta Arnolfa di Cambia znajdowała się na wysokości oczu kapłana, który celebrował przy umieszczonym niżej ołtarzu, zmuszając go niejako do patrzenia na sarkofag papieża ${ }^{63}$. Po poświęceniu mauzoleum w dniu 6 maja 1296 roku piękna leżąca postać Bonifacego VIII wzbudzała nie tylko podziw, ale również zdziwienie, a nawet zgorszenie. Bonaiuto da Casentino, poeta na dworze papieskim, zapisał, że w ten sposób Bonifacy VIII „zatrzymał czas”, a Bernard Gui relacjonował, że słynny herezjarcha Dulcyn z Novary był oburzony tym, że znienawidzony przez niego papież kazał sobie wykonać za życia pomnik z kamienia, na którym wygląda, jak żywy ${ }^{64}$.

Jakie przesłanie kryje $\mathrm{w}$ sobie ten piękny przykład późnośredniowiecznej sztuki sepulkralnej, obok którego przechodzą dzisiaj liczni pielgrzymi i turyści, zwiedzający Groty Watykańskie? Jak twierdzi Agostino Paravicini Bagliani, można zauważyć analogie pomiędzy przesłaniem zawartym w postaci papieża,

${ }^{61}$ Wydaje się, że mogło temu służyć również przeniesienie do mauzoleum relikwii św. Bonifacego IV papieża (†615). Jak twierdzi Agostino Paravicini Bagliani, „Bonifacy nie został wybrany następcą zmarłego papieża. Decyzja o przeniesieniu szczątków ciała papieża do jego własnej kaplicy grobowej miała na celu przywrócenie chwilowo przerwanej ciąłłości sukcesji apostolskiej w wymiarze cielesnym. Dla Bonifacego VIII brak ciała zmarłego poprzednika mógł być postrzegany jako problem w kontekście legitymizacji władzy, ponieważ w ostatnich dziesięcioleciach XIII wieku związek zachodzący pomiędzy śmiercią, pochówkiem i procedurą wyboru urósł do rangi nierozerwalnego związku o charakterze instytucjonalnym, silnego do tego stopnia, że przyczynił się do wydłużenia w czasie ceremonii pogrzebowych, a co za tym idzie, ukształtowania się zwyczaju dziewięciodniowych uroczystości żałobnych po śmierci papieża (novendiali)" - tamże; zob. również s. 320-321; tenże, Bonifacio VIII, s. 110; S. Romano, Visione e visibilità, s. 64-66.

${ }^{62}$ Zob. A. Paravicini Bagliani, Bonifacio VIII, s. 113.

${ }^{63}$ Bonifacius papa octavus [...] sepulcrum sibi vivens marmoreum cum insigni eius gentilicio parieti coaptavit ita, ut, dum sacerdos massae sacrum perageret, ipsius Bonifacii conspiceret - G. Grimaldi, Descrizione della basilica antica di S. Pietro in Vaticano, codice Barberiniano latino 2733, a cura di R. Niggl, Città del Vaticano 1972, s. 37.

${ }^{64}$ Secundum vero papam exponit et dicit esse Bonifacium octavum qui successit Celestino; et illo anno quo predicta littera Dulcini fuit scripta Bonifacius fuerat captus in mense septembri et obiit sequenti mense octobri; de quo exponit quod scribitur in Ysaia propheta de ascencione cameli [XXI,7] et proposito templi qui fecit sibi fieri monumentum, et ymaginem supra petram sicut esse viva - B. Gui, De secta illorum qui se dicunt esse de ordine Apostolorum, Rerum Italicarum Scriptores, 9/5, Roma 1907, s. 22-23; zob. A. Paravicini Bagliani, Bonifacio VIII, s. 115. 
umieszczonej na jego sarkofagu, i cytowanym wyżej komentarzem kardynała Lemoine do bulli Detestande feritatis, a także poglądami Rogera Bacona ${ }^{65}$. W wyniku reformy gregoriańskiej doktryna średniowiecznego papiestwa wzbogaciła się o nowe elementy. Jednym z nich był tytuł Vicarius Christi, używany dotychczas w odniesieniu do cesarza jako przedstawiciela Boga na ziemi. Święty Bernard z Clairvaux twierdził, że Chrystus ustanowił sobie na ziemi jedynego wikariusza, a jest nim papie $\dot{z}^{66}$. Tytuł ten stawia go w szczególnej relacji do Chrystusa, wyrażanej za pomocą zakorzenionej w Pawłowej nauce o Kościele metafory ciała, co zauważyć można w średniowiecznej refleksji chrystologicznej i eklezjologicznej, której przykładem jest De consideratione ${ }^{67}$. Przejawem tych nowych tendencji jest choćby słynne stwierdzenie Henryka z Suzy, Ubi papa, ibi Roma, czy spojrzenie na osobe papieża Bonifacego VIII, widoczne we wzmiance o zamachu w Anagni w dniu 7 września 1303 roku, zawartej w Boskiej Komedii Dantego ${ }^{68}$.

Warto w tym kontekście przyjrzeć się XIII-wiecznemu podejściu do ciała papieża jako konkretnej osoby. W ówczesnej literaturze zauważyć można przekonanie, że jako człowiek papież żyje krótko, a jego życie wypełniają liczne udręki, których kresem jest śmierć i rozkład ciała. Idee te przenikają do sztuki sepulkralnej, a przykładem tego jest grobowiec Klemensa IV (1265-1268) w kościele św. Franciszka w Viterbo. Epitafium przypomina, że jest już prochem „następca i spadkobierca Piotra”, a napięte rysy twarzy zmarłego epatują cierpieniem i śmiercią ${ }^{69}$. Jak twierdzi Agostino Paravicini Bagliani, „,el retoryki i rytuału przemijania, wyznaczony u zarania reformy gregoriańskiej, był jasny i fundamentalny: oddzielić ziemską i przemijającą osobę papieża od papieskiej godności o charakterze wiecznym"70. Zupełnie inaczej jawi się oglądającemu leżąca postać Bonifacego VIII z Grot Watykańskich. Brak w niej, przede wszyst-

${ }^{65}$ Zob. tenże, Il corpo del Papa, s. 339-340.

${ }^{66}$ Nempe signum singularis pontifici Petri, per quod non navem unam, ut caeteri quique suam, sed saeculum ipsum susceperit gubernandum. Mare enim saeculum est; naves, Ecclesiae. Inde est quod altera vice instar Domini gradiens super aquas, unicum se Christi vicarium designavit, qui non uni populo, sed cunctis praeesse deberet: siquidem „aquae multae, populi multi”. Ita cum quisque caeterorum habeat suam, tibi una commissa est grandissima navis; facta ex omnibus ipsa universalis Ecclesia, toto orbe diffusa - Sancti Bernardi Abbatis Claraevallensis De consideratione libri quinque ad Eugenium Tertium, II, VIII, 16, PL 182, 752.

${ }^{67}$ Zob. A. Paravicini Bagliani, Il corpo del Papa, s. 82-83.

68 „By mniej zło przeszłe i przyszłe raziło, / lilie francuskie wkroczą do Alagni; / w swym namiestniku Chrystus pojman siłą. / Widzę, jak znowu Go szyderstwo rani, / widzę, jak znów Go żółcią z octem poją, / jak życie kończy w złoczyńców kompanii” - Dante, Boska Komedia, Czyściec, XX, 88-93, tłum. A. Świderska, Kęty 1999, s. 308.

${ }^{69}$ Lector, fige pedes, / quam brevis aedes / pontificem quartum / Clementem contegit arctum. / / En datur in cineres / Petri successor et heres! - M. Guardo, Titulus et tumulus. Epitafi di pontefici e cardinali alla corte dei papi del XIII secolo, La corte dei papi, 17, Roma 2008, s. 53.

${ }^{70}$ A. Paravicini Bagliani, Il corpo del Papa, s. 341. 
kim, owego naznaczenia śmiercią, które tak bardzo rzuca się w oczy oglądającemu grobowiec Klemensa IV. Postać papieża dłuta Arnolfa di Cambia wyraża ideę nieśmiertelności, która obejmuje już nie tylko papieską godność, lecz także konkretną osobę papieża ${ }^{71}$. Jeśli dodać do tego zamiłowanie Bonifacego VIII do figur i rzeźb, przedstawiających jego osobę, widoczne już w okresie, gdy jako kardynał wyruszył z misją dyplomatyczną do Francji, gdzie dał się poznać jako zdecydowany obrońca prerogatyw Stolicy Apostolskiej, można przypuszczać, że zakaz naruszania integralności ludzkiego ciała wypływał z jego głębokich przekonań, które dały o sobie znać w bulli Detestande feritatis ${ }^{72}$.

Papieski dokument odbił się szerokim echem w późnym średniowieczu. Świadczą o tym, między innymi, XIV-wieczne testamenty znanych ówczesnych osobistości, które uwzględniają postanowienia zawarte w Detestande feritatis. Dotyczy to również krajów, takich jak Francja, w których praktyka krojenia i gotowania zwłok występowała częściej niż w Italiii³. W 1308 roku Karol II Andegaweński nakazał pochówek swojego ciała w kościele Notre Dame de Naza-

${ }^{71}$ Przed zbyt ścisłym łączeniem papiestwa jako godności z człowieczeństwem konkretnego papieża przestrzegał XIII-wieczny franciszkański teolog Piotr Olivi w liście z 14 września 1295 roku do Konrada z Offidy: Item addunt, quod eadem Christi auctoritate, qua Petrus factus est papa, fit et quilibet eius successor. Insanum autem est dicere, quod apostoli potuissent mutare Petri papatum, etiam cum eius beneplacito et assensu. Ex hiis autem concludunt, quod papatus est aliquid indelebile et inseparabile a substantia humanitatis eius, qui assumitur ad papatum, ut sicut in hostia consecrata, manentibus accidentibus, manet semper Christus, sic, manente humanitate pape, manet semper in eo sacramentaliter Chrisus seu Christi papatus [...] Quod vero dicunt, quod papa est ymago Christi eterni et immutabilis, ergo papa debet esse eternus et immutabilis; si bene arguunt, sequitur etiam, quod post mortem pape non possit substitui alius papa, quia constat, quod post mortem Christi non potuit substitui alius Christus. Unde autem sequitur, quod, quia papa vel episcopus est quoad aliquid Christi ymago, ergo quoad omnia est Christi ymago? - Petri Iohannis Olivi De renuntiatione papae Coelestini V. Quaestio et Epistola, "Archivum Franciscanum Historicum” 11 (1918), s. 367-368; zob. A. Paravicini Bagliani, Il corpo del Papa, s. 341-342.

${ }^{72}$ Misja dyplomatyczna do Francji miała miejsce w 1290 roku. Przyszły papież udał się tam wraz z kardynałem Gerardem Bianchim. Jedną ze spraw, z jakimi musieli się zmierzyć obydwaj legaci, był spór majątkowy pomiędzy arcybiskupem Reims i tamtejszą kapitułą. Po doprowadzeniu do ugody Caetani i Bianchi nakazali arcybiskupowi i kanonikom wykonanie dwóch przedstawiających ich srebrnych figur, które miały zostać umieszczone w katedrze i przypominać o władzy Rzy$\mathrm{mu}$, którą reprezentowali papiescy legaci. To śmiałe posunięcie zostało w późniejszym okresie wykorzystane przez wrogów papieża, którzy zarzucali mu zachęcanie wiernych do idolatrii. Zarzut ten pojawił się między innymi w przemówieniu Wilhelma Plaisiansa, wygłoszonym w Luwrze w dniach 13-14 września 1303 roku w obecności Filipa IV Pięknego: Item ut suam damnatissimam memoriam constituat, fecit imagines suas argenteas erigi in ecclesiis per hoc homines ad idolatrandum inducens - Boniface VIII en procès, s. 148; zob. tamże, s. 277-278, 419-420; T. Schmidt, Papst Bonifaz VIII. und die Idolatrie, „Quellen und Forschungen aus italienischen Archiven und Bibliotheken” 66 (1986), s. 75-107; J. Grzeszczak, Bonifacius-malefacius. Oskarżenia o kontakty ze ztym duchem w aktach procesu Bonifacego VIII z lat 1303-1311, „Poznańskie Studia Teologiczne" 20 (2006), s. 205; tenże, Problem herezji Bonifacego VIII $w$ aktach procesowych z lat 1303-1311, „Poznańskie Studia Teologiczne” 21 (2007), s. 241.

${ }^{73}$ Zob. E.A.R. Brown, Death and the Human Body, s. 250-251. 
reth w Aix-en-Provence, precyzując jednak, że gdyby umarł na terenie swojego Królestwa Obojga Sycylii, chce być czasowo pochowany w dominikańskim kościele w Neapolu ${ }^{74}$. W XIV wieku zdarzały się dość częste przypadki zwracania się do Stolicy Apostolskiej o dyspensę od postanowień bullii ${ }^{75}$. Jak twierdzi Elizabeth Brown, bezpośredni efekt papieskich rozporządzeń był jednak odwrotny od zamierzonego, ponieważ po roku 1300 pochówek części ciała w różnych miejscach stał się przywilejem zastrzeżonym dla nielicznych, a przez to znakiem ich wysokiego społecznego statusu ${ }^{76}$.

Świat medycyny późnego średniowiecza odniósł się na ogół ze zrozumieniem do postanowień bulli, broniących integralności ludzkiego ciała po śmier$\mathrm{ci}^{i 7}$. Najstarsze traktaty anatomiczne średniowiecza przenika świadomość, że w tradycji chrześcijańskiej obowiązuje szacunek dla ludzkiego ciała. Przedstawiciele szkoły z Salerno thumaczą nim upadek anatomii, do jakiego doszło na Zachodzie od momentu, gdy zamiast sekcji ludzkich ciał zaczęto przeprowadzać sekcje ciał zwierzat ${ }^{78}$. Podobnie jak w przypadku wspomnianych wyżej dyspens od postanowień bulli, również medycy musieli zwracać się z podobnymi prośbami do Stolicy Apostolskiej. Od końca XIII wieku mamy do czynienia z pojawieniem się prawdziwych autopsji, mających na celu ustalenie przyczyn zgonu. Działania te szły w parze z rozwojem ówczesnego prawa. Jak twierdzi Agostino Paravicini Bagliani, konieczność uzyskania papieskiej dyspensy w celu dokonania sekcji zwłok była rodzajem kompromisu pomiędzy wielowiekową tradycją nienaruszalności ludzkiego ciała a nowymi wymogami medycznymi i prawnymi, związanymi z rozwojem nauk w późnym średniowieczu ${ }^{79}$.

${ }^{74}$ Zob. tamże.

${ }^{75}$ Zob. tamże, s. 251-264.

76 "Thus, Detestande feritatis did not accomplish what Boniface VIII intended. Indeed, its immediate effect was inverse, for it made division of the body after death more desirable than before. After 1300 separate burial of the body's part was a privilege which only the most favored could obtain and it thus became a sure sign of status and distinction" - tamże, s. 264-265.

${ }^{77}$ Obok informacji świadczących o posłuszeństwie lekarzy wobec papieskich decyzji znaleźć można również świadectwa, których przykładem jest Guy de Chauliac, najwybitniejszy francuski chirurg późnego średniowiecza. Twierdzi on, że często przeprowadzał sekcje zwłok „wysuszonych na słońcu, rozłożonych w ziemi lub rozpuszczonych w bieżącej bądź wrzącej wodzie" - zob. A. Paravicini Bagliani, La papauté du XIII siècle et la renaissance de l'anatomie, s. 276.

${ }^{78}$ Zob. tamże, s. 277.

79 “C'est peut-être là que réside la véritable raison du «succès juridique» de la décretale de Boniface VIII: née pour interdire le dépecement du corps à des fins de transport, considérée comme un «crime» contre l'humanité, cette décrétale finit par servir de référence juridique obligatoire pour ceux qui s'adonnaient à l'anatomie. Le respect de cette décrétale ou, si l'on veut, l'octroi d'un privilège pontifical pour ouvrir un corps à des fins d'étude, constituait, finalement, une sorte de compromis, typiquement médiéval, entre la nécessité de satisfaire une tradition chrétienne millénaire - le respect dû à la dépouille mortelle - et les nouvelles exigences, judiciaires et médicales, provoquées par le raffinement des techniques judiciaires du droit canon et par le développement des nouvelles facultés de médicine de l'Europe médiévale" - tamże, s. 279. 


\section{ANEKS \\ Bonifacy VIII \\ Bulla Detestande feritatis ${ }^{80}$}

Ad perpetuam rei memoriam. Detestande feritatis abusum, quem ex quodam more horribili nonnulli fideles improvide prosecuntur, nos, pie intentionis ducti proposito, ne abusus predicti sevitia ulterius corpora humana dilaceret, mentesque fidelium horrore commoveat, et perturbet auditum, digne decrevimus abolendum. Prefati namque fideles, hujus sue improbande utique consuetitudinis vitio intendentes, si quisquam ex eis genere nobilis vel dignitatis titulo insignitus, presertim extra suarum partium limites debitum nature, persolvat, in suis vel aliis remotis partibus sepultura electa, defuncti corpus ex quodam impie pietatis affectu truculenter excuterant, ac illud membratim vel in frustra immaniter concidentes, ea subsequenter aquis immersa exponunt ignibus decoquenda; et tandem, ab ossibus tegumento carnis excusso, eadem ad partes predictas mittunt seu deferunt tumulanda. Quod non solum divine majestatis conspectui abominabile plurimum redditur, sed etiam humane considerationis obtutibus occurrit vehementius aborrendum. Volentes igitur, prout offici nostri debitum exigit, illud in hac parte remedium adhibere, per quod tante abominationis, tanteque immanitatis et impietatis abusus penitus deleatur, nec extendatur ad alios, Apostolica auctoritate statuimus et ordinamus, ut, cum quivis cujuscumque status aut generis seu dignitatis extiterint, in civitatibus, terris aut locis, in quibus catholice fidei cultus viget, diem de cetero claudet extremum, circa corpora defunctorum hujusmodi abusus vel similis nullatenus observetur, nec fidelium manus tanto immanitate fedentur. Sed, ut defunctorum corpora sic impie ac crudeliter non tractentur, deferantur ad loca, in quibus viventes elegerint sepeliri, aut in civitate, castro vel loco vicino ecclesiastice sepulture tradantur ad tempus, ita quod demum, incineratis corporibus ad alias, ad loca, ubi sepulturam elegerint, deportentur et sepeliantur in eis. Nos enim, si predicti defuncti executor vel executores, aut familiares ejus, seu quivis alii, cujuscumque ordinis, conditionis, status aut gradus fuerint, etiamsi pontificali dignitate prefulgeant, aliquid contra hujusmodi nostri statuti et ordinationis tenorem presumpserint attentare, defunctorum corpora sic inhumaniter pertractando, vel faciendo pertractari, excommunicationis sententiam, quam exnunc in ipsos proferimus, ipso facto se noverint incursuros, a qua non nisi per Apostolicam Sedem, preterquam in mortis articulo, possint absolutionis beneficium obtinere. Et nihilominus ille, cujus corpus sic inhumane tractatum fuerit, ecclesiastica careat sepultura. Nulli ergo, et cetera, nostri statuti ordinationis et prolationis, et cetera. Dat. Anagnie, IIII kal. octobris, anno quinto.

\footnotetext{
${ }^{80}$ Les Registres de Boniface VIII, t. II (1298-1301), red. G. Digard, M. Faucon, A. Thomas, R. Fawtier, Paris 1904, s. 576-577 (nr 3409).
} 


\section{Boniface VIII towards Medieval Funeral Customs. The Bull Detestande feritatis and its Interpretations}

\section{Summary}

On September 27, 1297 Pope Boniface VIII (1294-1303) promulgated a bull beginning with the words Detestande feritatis, thereby outlawing any further practice of the medieval custom of dismembering human corpses which were subsequently boiled in water to separate the bones from the soft tissue. This was a practice that facilitated burial in places remote from the scene of death of the deceased. The first part of the article presents the circumstances in which the papal document originated. By outlawing such practices the Pope invalidated the decisions contained in the last wills of some, especially the French, cardinals of his times. The custom of dismembering human corpses was predominantly practiced north of the Alps, but it was also present on the territory of today's Spain. In medieval times it was known as "the German custom" (mos teutonicus) and was underpinned by a specific medieval anthropology. The second part of the article scrutinizes the probable reasons of the Pope's violent reaction. An attempt is made to reconstruct the forma mentis of Boniface VIII. Relevant indications and clues can be found in the records of the proceedings against the Pope by Philip the Fair, king of France, in the iconography of monuments erected at the Pope's initiative, and also in the development of the natural sciences in the late Middle Ages.

\section{Keywords}

Boniface VIII, anatomy, human body

\section{Slowa kluczowe}

Bonifacy VIII, anatomia, ciało ludzkie 